\title{
Difficulties of patients and caregivers in performing clean intermittent catheterization: scoping review
}

\section{Dificuldades de pacientes e cuidadores na realização do cateterismo intermitente limpo: revisão de escopo}

\author{
Dificultades de los pacientes y cuidadores en la realización del cateterismo \\ intermitente limpio: revisión de alcance
}

Leonardo Orlandin",*, Aguinaldo Nardi², Raphael Raniere de Oliveira Costa ${ }^{3}$, Alessandra Mazzo

ORCID IDS

Orlandin L (D) https://orcid.org/0000-0002-3449-9837

Mazzo A (D) https://orcid.org/0000-0001-5074-8939

Nardi A (D) http://orcid.org/0000-0002-3095-5567

Costa RRO (D) https://orcid.org/0000-0002-2550-4155

\section{HOW TO CITE}

Orlandin L; Mazzo A; Nardi A; Costa RRO. Dificuldades de pacientes e cuidadores na realização do cateterismo intermitente limpo: revisão de escopo. ESTIMA, Braz. J. Enterostomal Ther., 18: e1520, 2020. https://doi.org/10.30886/estima.v18.907_IN

\begin{abstract}
Objective: To identify the main difficulties reported by patients and caregivers in the use of clean intermittent catheterization described in the scientific literature. Methods: Scoping review with studies published in Portuguese, English or Spanish, without date limit, in electronic databases and digital libraries, using descriptors and keywords. Results: 790 studies were identified, including 34 studies published between 1984 and 2019. The main difficulties reported in performing clean intermittent catheterization were related to catheter insertion, pain, discomfort, urethral trauma, public bathrooms with inadequate facilities, physical difficulties and lack of access to necessary inputs. Conclusion: The studies analyzed show the difficulties that patients who use clean intermittent catheterization and their caregivers face on a daily basis, which are related to intrinsic and extrinsic, institutional and governmental factors and can decrease satisfaction and adherence to rehabilitation programs bladder, with an impact on the quality of life of patients and their caregivers. Therefore, it highlights the need for health education for the proper teaching of performing clean intermittent catheterization, emphasizing the importance of the nurse's role in this process.
\end{abstract}

DESCRIPTORS: Intermittent urethral catheterization; Urinary bladder; neurogenic; Rehabilitation; Enterostomal therapy.

\footnotetext{
1. Universidade de São Paulo - Escola de Enfermagem de Ribeirão Preto - Programa de Pós-Graduação em Enfermagem Fundamental - Ribeirão Preto (SP), Brazil.

2. Universidade de São Paulo - Faculdade de Odontologia de Bauru - Curso de Medicina - Bauru (SP), Brazil.

3. Universidade Federal do Rio Grande do Norte - Escola Multicampi de Ciências Médicas - Caicó (RN), Brazil.

*Correspondence author: leonardo.orlandin@usp.br

Received: Jun. 19, 2020 | Accepted: Ago. 10, 2020
} 


\section{RESUMO}

Objetivo: Identificar as principais dificuldades relatadas pelos pacientes e cuidadores no uso do cateterismo intermitente limpo descritas na literatura científica. Métodos: Revisão de escopo com estudos publicados em português, inglês ou espanhol, sem limite de data, em base de dados eletrônicas e bibliotecas digitais, utilizando descritores e palavras-chave. Resultados: Foram identificados 790 estudos, sendo incluídos 34 estudos publicados entre 1984 e 2019. As principais dificuldades relatadas na realização do cateterismo intermitente limpo foram referentes a inserção do cateter, dor, desconforto, trauma uretral, banheiros públicos com instalações inadequadas, dificuldades físicas e falta de acesso aos insumos necessários. Conclusão: Os estudos analisados evidenciam as dificuldades que os pacientes usuários do cateterismo intermitente limpo e seus cuidadores enfrentam no dia a dia, que estão relacionadas à fatores intrínsecos e extrínsecos, institucionais e governamentais e podem diminuir a satisfação e a aderência aos programas de reabilitação vesical, com impacto na qualidade de vida dos pacientes e seus cuidadores. Portanto destaca-se a necessidade de educação em saúde para o adequado ensino da realização do cateterismo intermitente limpo, enfatizando a importância do papel do enfermeiro nesse processo.

DESCRITORES: Cateterismo uretral intermitente; Bexiga urinária neurogênica; Reabilitação; Estomaterapia.

\section{RESUMEN}

Objetivo: Identificar las principales dificultades reportadas por pacientes y cuidadores en el uso de cateterismo intermitente limpio descrito en la literatura científica. Métodos: Revisión de alcance con estudios publicados en portugués, inglés o español, sin límite de fecha, en base de datos electrónica y bibliotecas digitales, utilizando descriptores y palabras clave. Resultados: Se identificaron 790 estudios, que incluyó 34 estudios publicados entre 1984 y 2019. Las principales dificultades señaladas para realizar cateterismo intermitente limpio se relacionaron con la inserción del catéter, dolor, molestias, traumatismo uretral, baños públicos con instalaciones inadecuadas, dificultades físicas y falta de acceso a los insumos necesarios. Conclusión: Los estudios analizados muestran las dificultades que los pacientes que usan cateterismo intermitente limpio y sus cuidadores enfrentan a diario, que están relacionadas con factores intrínsecos y extrínsecos, institucionales y gubernamentales y pueden disminuir la satisfacción y el cumplimiento de los programas de rehabilitación de la vejiga, con un impacto en la calidad de vida de los pacientes y sus cuidadores. Por lo tanto, se destaca la necesidad de educación sanitaria para la enseñanza adecuada de la realización de cateterismo intermitente limpio, haciendo hincapié en la importancia del papel de la enfermera en este proceso.

DESCRIPTORES: Cateterismo uretral intermitente; Vejiga urinaria neurogénica; Rehabilitación; Estomaterapia.

\section{INTRODUCTION}

Clean intermittent catheterization (CIC) consists of the periodic insertion of a bladder catheter in order to eliminate its contents and promote bladder emptying. It is one of the main interventions adopted for urinary dysfunctions that have difficulty in bladder emptying caused or not by neurological pathologies ${ }^{1-4}$.

The procedure aims to prevent complications associated with urinary stasis, such as urinary tract infection and upper urinary tract lesions. The CIC makes it possible to protect the urinary tract and improve eventual urinary incontinence and quality of life in its social spheres of self-esteem and autonomy ${ }^{1,3}$. The occurrence of technical difficulties in performing the procedure may contribute to discontinuity and lower probability of CIC use and, consequently, cause consequences of not treating the neurogenic bladder ${ }^{5}$.

Because it is an invasive procedure, it can cause pain and discomfort, besides offering risks in its performance. Urethral trauma is often related to the introduction of the nonlubricated catheter, the type of material used and the technique adopted to perform the procedure. Urethral trauma occurs by the friction of the badly lubricated catheter against the urethral mucosa and is characterized by urethral pain and/or bleeding. In addition, it offers a gateway for bacteria responsible for the development of urinary tract infections. When performed over a long period, it can result in urethral stenosis, urinary incontinence, erectile dysfunction and infertility ${ }^{1,6,7}$.

The characteristics of the materials used to perform the procedure may have an impact on the success or not of the technique, since some of these catheters may offer greater ease of handling and execution and less pain and discomfort to the introduction ${ }^{1,8-11}$. In Brazil, patients have access to polyvinyl urinary catheter (PVC), a low-cost, flexible material without lubricants by the Unified Health System (Sistema Único de Saúde, SUS) ${ }^{12}$. Its use is usually associated with increased catheter friction against the urethral mucosa and, consequently, increased risk of urethral trauma. The use of prelubricated hydrophilic catheters can make the procedure more precise and safer ${ }^{2,11,13-15}$. 
In this context of diversified materials and the need for patient compliance to carry out the treatment and risks inherent to the procedure, it is essential for professionals to master the ability to promote educational actions. Effective educational actions in health only come about when they recognize the reality and previous experiences of the individuals for whom they are intended, determining potentialities and susceptibilities, in an integral view, which establish teaching-learning objectives in face of the difficulties encountered. Thus, it is necessary to be aware of the difficulties encountered by patients and/or their caregivers in developing the technique, in order to identify errors and ensure better quality of life for CIC users ${ }^{16}$.

Some studies point out as the greatest difficulty in the realization of the CIC the lack of mastery of the technique by patients and/or their caregivers. The positioning of the patient during the procedure, the adequate visualization of the urethral meatus, the knowledge of the method and of the urethral anatomy allow the patients and their caregivers to probe the urethra without trauma and pain, avoiding maneuvers that may damage the urethra ${ }^{5,17}$. Hence, the systematization of the procedure is fundamental.

In this sense, this study aims to identify the main difficulties reported by patients and caregivers in the use of clean intermittent catheterization described in the scientific literature.

\section{METHODS}

Study carried out using the scope review as proposed by the Joanna Briggs Institute $(\mathrm{JBI})^{18}$. For the construction of the research question, the PCC strategy that represents a mnemonic for Population, Concept and Context, thus defined, was applied: $\mathrm{P}=$ patients or caregivers, $\mathrm{C}=$ difficulties and $\mathrm{C}=$ performing clean intermittent catheterization. For the search and selection of studies, the following guiding question was established: "What are the difficulties of patients and/or caregivers during the performance of clean intermittent catheterization?"

The search was performed by two independent researchers, according to JBI criteria ${ }^{18}$, without date limit, in the following databases and digital libraries: Scientific Electronic Library Online (SciELO) and
Library of Knowledge Online (B-on), Latin American and Caribbean Literature in Health Sciences (LILACS), National Library of Medicine (PubMed), The Cochrane Library, Web of Science, Scopus, Cumulative Index to Nursing and Allied Health Literature (CINAHL) and Academic Search Premier (via EBSCO platform).

The gray literature was identified through searches carried out in the CAPES theses database, Digital Library of Theses and Dissertations of the University of São Paulo (USP) and USP's Integrated Search Porta1 ${ }^{18}$. The references cited in the studies found were also considered to identify possible studies of additional interest to the search ${ }^{19}$.

For this, descriptors, keywords and/or their synonyms were used, according to the Descriptors in Health Sciences (DeCS) and Medical Subject Headings (MeSH) for each strategy item. Thus, the following descriptors were used for Population (P): paciente AND cuidadores OR patient AND caregivers; Concept (C): "dificuldade" OR "dificuldades" OR "difficulty" OR "difficulties"; Context (C): "cateterismo uretral intermitente" OR "cateterismo intermitente" OR "cateterismo urinário intermitente limpo" OR "intermittent catheterization" OR "clean intermittent catheterization" OR "intermittent urethral catheterization" OR "urethral self-catheterization".

For the combination of descriptors, the Boolean terms AND and OR were considered. After the search, studies in Portuguese, English and Spanish were included, with a quantitative and qualitative approach, primary studies, revisions, meta-analyses and/or metasynthesis, books and scripts, theses and dissertations, published in indexed sources or in grey literature. The searches were carried out between the months of May and June 2019, period during which all publications were accessed.

For the selection of studies, a careful reading of the title, abstract and keywords was performed, in order to analyze the adequacy to the established inclusion and exclusion criteria. On those occasions when the title, abstract and descriptors were not enough to define the selection, the article was read in its entirety.

For the extraction of the data, the instrument structured by the researchers themselves was used according to the JBI's recommendations ${ }^{18}$. For the presentation of results, the studies were numbered and named "study". In the critical analysis of the selected articles, the outline of the studies was also analyzed. 


\section{RESULTS}

From the searches carried out, 790 potential studies were identified. After reading the titles and abstracts, 95 studies were selected for full reading, 33 of which were excluded because they were repeated. After full analysis of the 62 selected studies, 34 were included because they answered the research question. The description of the selection process and inclusion of studies is represented in Fig. 1.

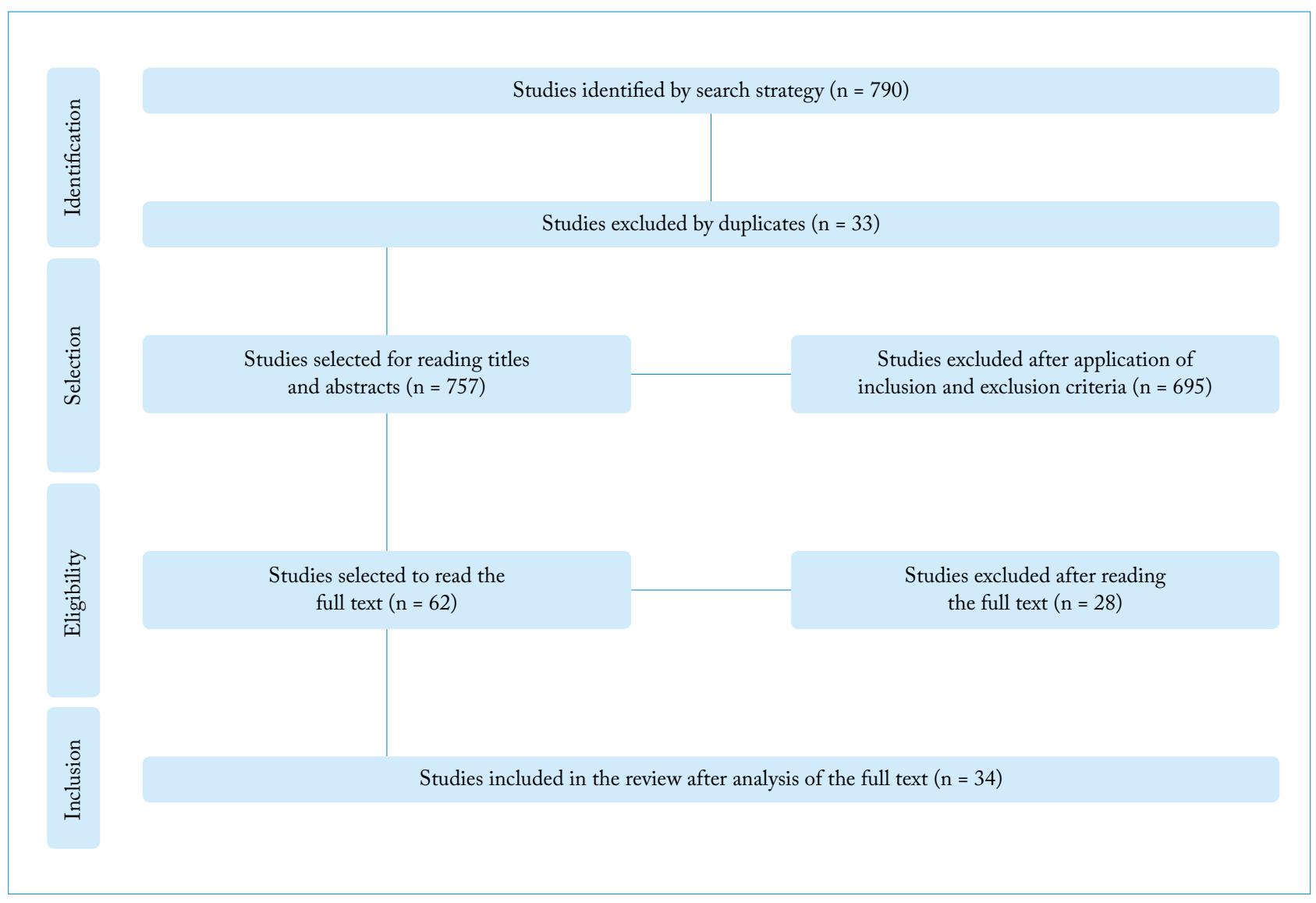

Figure 1. Flow diagram of the process of selection and inclusion of studies. Ribeirão Preto (SP), Brazil, 2019.

The 34 selected studies were published in English (88.0\%), Portuguese (9.0\%) and Spanish (3.0\%), the majority (94.0\%) being scientific articles published in the area of medicine (64.7\%) nursing (26.4\%) and partnerships between medicine and nursing (9.0\%). The studies were carried out from 1984 to 2019 and, among them, 7 (20.6\%) were published between the 1980s and 90s, 7 (20.6\%) between the 2000s and 2010s and 20 (58.8\%) were published between 2011 and 2019, which may point to an increase in interest in the subject.

Table 1 presents the selected studies according to sample $n$ and mean age in years, type of participant, methodological design, objectives of the study and main difficulties reported in the CIC execution.
The studies pointed out as difficulties in performing clean intermittent catheterization the difficulty in catheter insertion (64.7\%), pain (35.0\%), urethral trauma and bleeding $(26.4 \%)$, precarious installations in public bathrooms (26.4\%), motor and/or visual physical difficulties (23.5\%), difficulty in body positioning (23.5\%), discomfort $(20.5 \%)$, the time spent preparing the material and performing the procedure (15.0\%), the lack of access to necessary inputs (12.0\%), muscle spasms (12.0\%), difficulty in handling the prelubricated catheter because it is slippery (9.0\%), fear in performing the procedure (9.0\%), the presence of menstrual flow in females (6.0\%), the absence of the caregiver $(6.0 \%)$, the presence of fecaloma (3.0\%) and obesity (3.0\%). 
Table 1. Studies included according to sample $\mathrm{n}$ and mean age in years, type of participant, methodological design, objectives of the study and main difficulties reported in performing clean intermittent catheterization. Ribeirão Preto (SP), Brazil, 2019.

\begin{tabular}{|c|c|c|c|c|c|}
\hline Study & $\begin{array}{l}\text { Sample } \\
\text { (average } \\
\text { age in } \\
\text { years) }\end{array}$ & Participant & $\begin{array}{l}\text { Methodological } \\
\text { design }\end{array}$ & Objectives of the study & Main difficulties reported \\
\hline $1^{20}$ & $\begin{array}{l}65 \\
(67)\end{array}$ & Patients & $\begin{array}{l}\text { Quantitative, } \\
\text { transversal, } \\
\text { descriptive }\end{array}$ & $\begin{array}{l}\text { Present data of patients } 65 \text { years } \\
\text { or older in use of CIC. }\end{array}$ & $\begin{array}{l}\text { Difficulty of catheter insertion due } \\
\text { to anatomical anomaly (prostate } \\
\text { calculus); urethral stenosis. }\end{array}$ \\
\hline $2^{21}$ & $\begin{array}{c}24 \\
(15.1)\end{array}$ & Patients & $\begin{array}{l}\text { Quantitative, } \\
\text { transversal, } \\
\text { descriptive }\end{array}$ & $\begin{array}{l}\text { Report the experience with } 24 \\
\text { children with spina bifida who } \\
\text { have physical and, in some cases, } \\
\text { mental disabilities. }\end{array}$ & $\begin{array}{l}\text { Difficulty in motor and ocular } \\
\text { coordination; curvature of the } \\
\text { spine makes it difficult to perform } \\
\text { the CIC; menstrual period; } \\
\text { anatomical abnormality (in the } \\
\text { bladder or spine). }\end{array}$ \\
\hline $3^{22}$ & $\begin{array}{c}158 \\
(32.5)\end{array}$ & Patients & $\begin{array}{l}\text { Quantitative, } \\
\text { transversal, } \\
\text { descriptive }\end{array}$ & $\begin{array}{l}\text { Evaluate whether the bladder neck } \\
\text { protrusion is normal or results } \\
\text { from a pathological process and } \\
\text { its functional significance. }\end{array}$ & $\begin{array}{l}\text { Difficulty in the insertion of the } \\
\text { catheter due to the protrusion; } \\
\text { need to manipulate the catheter } \\
\text { with application of force. }\end{array}$ \\
\hline $4^{23}$ & - & Articles & Review article & Describe the CIC practices. & $\begin{array}{l}\text { Lack of dexterity and/or mental } \\
\text { capacity; inadequate facilities in } \\
\text { public bathrooms or at home; } \\
\text { urethral bleeding. }\end{array}$ \\
\hline $5^{24}$ & $\begin{array}{c}16 \\
(11)\end{array}$ & Patients & $\begin{array}{l}\text { Quantitative, } \\
\text { prospective, } \\
\text { descriptive }\end{array}$ & $\begin{array}{l}\text { Evaluate the incidence and } \\
\text { types of postoperative urological } \\
\text { complications in patients with } \\
\text { myelomeningocele. }\end{array}$ & $\begin{array}{l}\text { Alteration of body posture; } \\
\text { plastered immobilization } \\
\text { of the spine. }\end{array}$ \\
\hline $6^{25}$ & $\begin{array}{c}90 \\
\text { (children) }\end{array}$ & Patients & $\begin{array}{l}\text { Quantitative, } \\
\text { prospective, } \\
\text { descriptive }\end{array}$ & $\begin{array}{c}\text { Evaluate functional urologic } \\
\text { sequelae related to lower urinary } \\
\text { tract dysfunction. }\end{array}$ & $\begin{array}{l}\text { Causes distress; sensitivity and } \\
\text { pain; difficult catheterization after } \\
\text { rectourethral fistula construction. }\end{array}$ \\
\hline $7^{26}$ & $\begin{array}{c}18 \\
(8.9)\end{array}$ & Patients & $\begin{array}{l}\text { Quantitative, } \\
\text { prospective, } \\
\text { descriptive }\end{array}$ & $\begin{array}{l}\text { Update the results and describe } \\
\text { other aspects to improve the } \\
\text { neourethra surgical technique } \\
\text { (Pippi Salle). }\end{array}$ & $\begin{array}{l}\text { Pain during CIC; limited motor } \\
\text { skills; need to change } \\
\text { body position. }\end{array}$ \\
\hline $8^{27}$ & $\begin{array}{l}39 \\
(45)\end{array}$ & Patients & $\begin{array}{l}\text { Quantitative, } \\
\text { prospective, } \\
\text { descriptive }\end{array}$ & $\begin{array}{l}\text { Evaluate the use of prelubricated } \\
\text { catheter in men who have been } \\
\text { using conventional catheter for a } \\
\text { long time. }\end{array}$ & $\begin{array}{l}\text { Difficulty in introducing the } \\
\text { catheter due to spasms; difficulty } \\
\text { in manipulating prelubricated } \\
\text { catheter because it is slippery; } \\
\text { bleeding and false path. }\end{array}$ \\
\hline $9^{28}$ & $\begin{array}{c}35 \\
(14.6)\end{array}$ & Patients & $\begin{array}{l}\text { Quantitative, } \\
\text { prospective, } \\
\text { descriptive }\end{array}$ & $\begin{array}{l}\text { Verify if the use of hydrophilic } \\
\text { catheter guarantees greater } \\
\text { satisfaction than the usual PVC } \\
\text { catheters. }\end{array}$ & $\begin{array}{l}\text { Difficulty in catheter insertion; } \\
\text { discomfort in catheter removal; } \\
\text { time of material preparation; } \\
\text { difficulty in manipulating } \\
\text { prelubricated catheter } \\
\text { because it is slippery. }\end{array}$ \\
\hline $10^{29}$ & $\begin{array}{c}62 \\
(39.6)\end{array}$ & Patients & $\begin{array}{l}\text { Quantitative, } \\
\text { prospective, } \\
\text { randomized, } \\
\text { multicentric }\end{array}$ & $\begin{array}{c}\text { Compare the use of lubricated } \\
\text { catheter and PVC catheter in } \\
\text { patients using CIC. }\end{array}$ & $\begin{array}{l}\text { Difficulty in catheter insertion; } \\
\text { macroscopic hematuria. }\end{array}$ \\
\hline $11^{30}$ & $\begin{array}{c}1 \\
(84)\end{array}$ & Patients & Case report & $\begin{array}{l}\text { Describe an unusual case of a } \\
\text { giant fecaloma in the pelvis. }\end{array}$ & $\begin{array}{l}\text { Difficulty in catheter insertion due } \\
\text { to obstruction caused by } \\
\text { giant fecaloma. }\end{array}$ \\
\hline
\end{tabular}


Tabela 1. Continuation...

\begin{tabular}{|c|c|c|c|c|c|}
\hline Study & $\begin{array}{l}\text { Sample } \\
\text { (average } \\
\text { age in } \\
\text { years) }\end{array}$ & Participant & $\begin{array}{l}\text { Methodological } \\
\text { design }\end{array}$ & Objectives of the study & Main difficulties reported \\
\hline $12^{31}$ & $\begin{array}{c}20 \\
(12.3)\end{array}$ & $\begin{array}{l}\text { Patients } \\
\text { and } \\
\text { caregivers }\end{array}$ & $\begin{array}{l}\text { Quantitative, } \\
\text { transversal, } \\
\text { descriptive }\end{array}$ & $\begin{array}{l}\text { Evaluate children with genital } \\
\text { sensitivity using } \mathrm{CIC} \text { and evaluate } \\
\text { experience with the technique and } \\
\text { quality of life of these patients and } \\
\text { their parents. }\end{array}$ & $\begin{array}{l}\text { Apprehension; discomfort; } \\
\text { unwillingness of the child to learn } \\
\text { the technique. }\end{array}$ \\
\hline $13^{32}$ & $\begin{array}{c}31 \\
(0.9)\end{array}$ & Patients & $\begin{array}{l}\text { Quantitative, } \\
\text { prospective, } \\
\text { descriptive }\end{array}$ & $\begin{array}{c}\text { Assess the rate of CIC } \\
\text { complication in relation to } \\
\text { puberty, autocatheterism and } \\
\text { catheter size. }\end{array}$ & $\begin{array}{l}\text { Urethral bleeding; difficulty in } \\
\text { insertion due to urethral polyps. }\end{array}$ \\
\hline $14^{33}$ & $\begin{array}{l}15 \\
(65)\end{array}$ & Patients & $\begin{array}{l}\text { Qualitative } \\
\text { based on } \\
\text { grounded } \\
\text { theory }\end{array}$ & $\begin{array}{l}\text { Describe the experience of people } \\
\text { in the realization of } \mathrm{CIC} \text { and the } \\
\text { impact on their quality of life. }\end{array}$ & $\begin{array}{c}\text { Difficulty in finding public } \\
\text { bathrooms with adequate } \\
\text { facilities; difficulty in inserting the } \\
\text { catheter due to muscle spasms; } \\
\text { discomfort and pain (men); } \\
\text { difficulty in visualizing the urethral } \\
\text { meatus (women); poor manual } \\
\text { dexterity. }\end{array}$ \\
\hline $15^{34}$ & $\begin{array}{c}8 \\
(45)\end{array}$ & Patients & Case report & $\begin{array}{l}\text { Describe practical difficulties in the } \\
\text { realization of the CIC. }\end{array}$ & $\begin{array}{l}\text { Lack of physical structure } \\
\text { in public bathrooms; lack of } \\
\text { time; lack of human resources } \\
\text { (caregiver); difficulty in visualizing } \\
\text { the urethra; type of material used } \\
\text { (catheter); resistance, bleeding } \\
\text { and false path. }\end{array}$ \\
\hline $16^{35}$ & - & Articles & Review article & $\begin{array}{l}\text { Review CIC in women, including its } \\
\text { advantages and disadvantages. }\end{array}$ & $\begin{array}{l}\text { Pain and bleeding; difficulty } \\
\text { in catheter insertion and/ } \\
\text { or removal; decreased visual } \\
\text { acuity; reduced dexterity; } \\
\text { reduced mobility; anatomical } \\
\text { abnormalities; difficulty in locating } \\
\text { the urethral meatus in women; } \\
\text { anxiety and discomfort. }\end{array}$ \\
\hline $17^{36}$ & $\begin{array}{c}1 \\
(75)\end{array}$ & Patients & Case report & $\begin{array}{l}\text { Report the case of a patient with } \\
\text { detrusor dysfunction and small } \\
\text { prostate protrusion. }\end{array}$ & $\begin{array}{l}\text { Difficulty in inserting the } \\
\text { catheter due to a slight prostate } \\
\text { enlargement. }\end{array}$ \\
\hline $18^{37}$ & $\begin{array}{c}1 \\
(13)\end{array}$ & Patients & Case report & $\begin{array}{l}\text { Describe a case of a common } \\
\text { technique for labiaplasty. }\end{array}$ & $\begin{array}{l}\text { Difficulty of access to the urethra } \\
\text { and insertion of the catheter by } \\
\text { hypertrophy of the small lips. }\end{array}$ \\
\hline $19^{38}$ & $\begin{array}{c}44 \\
(56)\end{array}$ & Patients & $\begin{array}{l}\text { Quantitative, } \\
\text { transversal, } \\
\text { descriptive }\end{array}$ & $\begin{array}{c}\text { Identify self-reported barriers } \\
\text { to CIC, describe associated } \\
\text { complications, examine CIC } \\
\text { adherence, and evaluate reported } \\
\text { quality of life. }\end{array}$ & $\begin{array}{l}\text { Lack of access to public } \\
\text { bathrooms with adequate } \\
\text { infrastructure; body positioning } \\
\text { for catheter introduction; lack of } \\
\text { dexterity and spasticity. }\end{array}$ \\
\hline $20^{3}$ & $\begin{array}{c}49 \\
(33.9)\end{array}$ & Patients & $\begin{array}{l}\text { Quantitative, } \\
\text { transversal, } \\
\text { descriptive and } \\
\text { correlational }\end{array}$ & $\begin{array}{l}\text { Investigate factors that interfere } \\
\text { with the continuity of } \mathrm{CIC} \text { and } \\
\text { verify if there is a significant } \\
\text { relationship with social support. }\end{array}$ & $\begin{array}{c}\text { Lack of infrastructure; financial } \\
\text { limitation; pain and discomfort; } \\
\text { urethral trauma. }\end{array}$ \\
\hline
\end{tabular}


Tabela 1. Continuation...

\begin{tabular}{|c|c|c|c|c|c|}
\hline Study & $\begin{array}{l}\text { Sample } \\
\text { (average } \\
\text { age in } \\
\text { years) }\end{array}$ & Participant & $\begin{array}{l}\text { Methodological } \\
\text { design }\end{array}$ & Objectives of the study & Main difficulties reported \\
\hline $21^{39}$ & $\begin{array}{c}7 \\
(10.1)\end{array}$ & Patients & $\begin{array}{l}\text { Qualitative } \\
\text { developed on } \\
\text { the sensitive } \\
\text { critical method }\end{array}$ & $\begin{array}{l}\text { Describe the care practices in the } \\
\text { clean bladder autocatheterism } \\
\text { carried out at home and various } \\
\text { spaces by school children and the } \\
\text { challenges faced. }\end{array}$ & $\begin{array}{l}\text { Difficulty in visualizing the } \\
\text { female urethral meatus with } \\
\text { the need to use a device for } \\
\text { visualization of the urinary } \\
\text { meatus; difficulty in positioning } \\
\text { to perform the technique; } \\
\text { discomfort with probing, pain } \\
\text { and burning; lack of motor skills; } \\
\text { lack of infrastructure in public } \\
\text { bathrooms. }\end{array}$ \\
\hline $22^{40}$ & $\begin{array}{l}174 \\
(11)\end{array}$ & $\begin{array}{l}\text { Patients } \\
\text { and } \\
\text { caregivers }\end{array}$ & $\begin{array}{l}\text { Qualitative, } \\
\text { transversal, } \\
\text { descriptive }\end{array}$ & $\begin{array}{l}\text { Analyze the quality of life of the } \\
\text { caregiver-child binomial and } \\
\text { identify factors involved in joining } \\
\text { the CIC program. }\end{array}$ & $\begin{array}{l}\text { Difficulty in acquiring materials, } \\
\text { adequate place to perform the } \\
\text { CIC, routines and overload of } \\
\text { the procedure (social nature); } \\
\text { menstruation; pain and } \\
\text { discomfort while performing } \\
\text { the CIC. }\end{array}$ \\
\hline $23^{41}$ & $\begin{array}{c}70 \\
(56.1)\end{array}$ & Patients & $\begin{array}{l}\text { Review } \\
\text { article and } \\
\text { methodological } \\
\text { study }\end{array}$ & $\begin{array}{c}\text { Build and validate a specific } \\
\text { questionnaire for difficulties } \\
\text { during CIC. }\end{array}$ & $\begin{array}{l}\text { Muscle spasm and stiffness; } \\
\text { local bleeding; high } \\
\text { sensitivity to pain; } \\
\text { complication of the disease. }\end{array}$ \\
\hline $24^{5}$ & $\begin{array}{c}200 \\
(14.5)\end{array}$ & $\begin{array}{l}\text { Patients } \\
\text { and } \\
\text { caregivers }\end{array}$ & $\begin{array}{l}\text { Quantitative, } \\
\text { transversal, } \\
\text { descriptive }\end{array}$ & $\begin{array}{l}\text { Identify and analyze the factors } \\
\text { that may contribute to the } \\
\text { discontinuity of CIC in Brazil and } \\
\text { Germany. }\end{array}$ & $\begin{array}{l}\text { Restless child; difficulty in } \\
\text { positioning and controlling the } \\
\text { torso; resistance in the sphincter } \\
\text { when introducing the catheter; } \\
\text { difficulty in visualizing the urethral } \\
\text { meatus; urethral sensitivity } \\
\text { and pain. }\end{array}$ \\
\hline $25^{42}$ & $\begin{array}{c}11 \\
(57)\end{array}$ & Patients & $\begin{array}{l}\text { Qualitative } \\
\text { with thematic } \\
\text { content } \\
\text { analysis }\end{array}$ & $\begin{array}{l}\text { Investigate barriers and facilitators } \\
\text { for patients dealing with CIC in } \\
\text { daily life. }\end{array}$ & $\begin{array}{l}\text { Difficulty in preparing materials } \\
\text { and performing hygiene; Lack of } \\
\text { accessibility and infrastructure in } \\
\text { public bathrooms; Need to change } \\
\text { body position; }\end{array}$ \\
\hline $26^{43}$ & $\begin{array}{c}60 \\
(13)\end{array}$ & $\begin{array}{l}\text { Patients } \\
\text { and } \\
\text { caregivers }\end{array}$ & $\begin{array}{l}\text { Quantitative, } \\
\text { prospective, } \\
\text { descriptive }\end{array}$ & $\begin{array}{l}\text { Research the current barriers } \\
\text { related to CIC in Korean patients } \\
\text { with spinal dysraphism. }\end{array}$ & $\begin{array}{l}\text { Lack of adequate location in the } \\
\text { school to perform the CIC; time } \\
\text { spent performing the technique; } \\
\text { unavailability of someone to assist } \\
\text { in the procedure. }\end{array}$ \\
\hline $27^{44}$ & $\begin{array}{l}12 \\
(-)\end{array}$ & Caregivers & $\begin{array}{l}\text { Qualitative } \\
\text { with thematic } \\
\text { content } \\
\text { analysis }\end{array}$ & $\begin{array}{c}\text { Understand the feelings } \\
\text { experienced by relatives } \\
\text { when caring for a child with a } \\
\text { neurogenic bladder dependent } \\
\text { on CIC. }\end{array}$ & $\begin{array}{l}\text { Fear of not introducing the } \\
\text { catheter into the urethral meatus; } \\
\text { difficulty in visualizing the urethral } \\
\text { meatus; fear of causing pain to the } \\
\text { child during the procedure; denial } \\
\text { of the new reality. }\end{array}$ \\
\hline $28^{45}$ & $\begin{array}{c}78 \\
(13.2)\end{array}$ & Patients & $\begin{array}{l}\text { Quantitative, } \\
\text { prospective, } \\
\text { experimental, } \\
\text { randomized }\end{array}$ & $\begin{array}{l}\text { Compare hydrophilic catheter to } \\
\text { standard uncoated catheter in } \\
\text { children with neurogenic bladder. }\end{array}$ & $\begin{array}{c}\text { Difficulty in handling prelubricated } \\
\text { catheter because it is slippery; } \\
\text { difficulty in inserting the catheter; } \\
\text { urethral pain. }\end{array}$ \\
\hline
\end{tabular}


Tabela 1. Continuation...

\begin{tabular}{|c|c|c|c|c|c|}
\hline Study & $\begin{array}{l}\text { Sample } \\
\text { (average } \\
\text { age in } \\
\text { years) }\end{array}$ & Participant & $\begin{array}{l}\text { Methodological } \\
\text { design }\end{array}$ & Objectives of the study & Main difficulties reported \\
\hline $29^{17}$ & $\begin{array}{c}55 \\
(31.7)\end{array}$ & $\begin{array}{l}\text { Patients } \\
\text { and } \\
\text { caregivers }\end{array}$ & $\begin{array}{l}\text { Quantitative, } \\
\text { prospective, } \\
\text { quasi- } \\
\text { experimental }\end{array}$ & $\begin{array}{l}\text { Evaluate the implications of } \\
\text { low-fidelity simulation in the } \\
\text { competence of patients and } \\
\text { caregivers in the use of } \\
\text { lubricants for CIC. }\end{array}$ & $\begin{array}{l}\text { Bleeding and urethral trauma; } \\
\text { negative urine drainage; resistance } \\
\text { in the introduction of the catheter. }\end{array}$ \\
\hline $30^{46}$ & $\begin{array}{c}202 \\
(73.7)\end{array}$ & Patients & $\begin{array}{l}\text { Quantitative, } \\
\text { retrospective } \\
\text { cohort }\end{array}$ & $\begin{array}{c}\text { Explore predictors of success in } \\
\text { learning CIC in patients over } 65 \\
\text { years of age. }\end{array}$ & $\begin{array}{l}\text { Functional and cognitive disability; } \\
\text { obesity; difficulty in accessing the } \\
\text { perineum and urethral meatus; } \\
\text { motor difficulty/deficiency; } \\
\text { anatomical abnormalities; } \\
\text { sensitivity disorders. }\end{array}$ \\
\hline $31^{47}$ & $\begin{array}{c}49 \\
(53)\end{array}$ & Patients & $\begin{array}{l}\text { Quantitative, } \\
\text { prospective, } \\
\text { descriptive }\end{array}$ & $\begin{array}{c}\text { Evaluate adherence to } \\
\text { anticholinergic therapy and CIC } \\
\text { in multiple sclerosis patients and } \\
\text { identify factors associated } \\
\text { with adherence. }\end{array}$ & $\begin{array}{l}\text { Resistance (feeling of blockage) } \\
\text { in catheter insertion; need to } \\
\text { change body positioning; need to } \\
\text { insert fingers to perform } \\
\text { the technique. }\end{array}$ \\
\hline $32^{48}$ & $\begin{array}{c}42 \\
(>65)\end{array}$ & Patients & $\begin{array}{l}\text { Quantitative, } \\
\text { prospective, } \\
\text { descriptive }\end{array}$ & $\begin{array}{l}\text { Determine the effectiveness and } \\
\text { safety of CIC in patients with cauda } \\
\text { equina syndrome. }\end{array}$ & $\begin{array}{l}\text { Patients over } 65 \text { years of age } \\
\text { presented greater difficulty in } \\
\text { performing the CIC } \\
\text { (catheter insertion). }\end{array}$ \\
\hline $33^{49}$ & $\begin{array}{c}97 \\
(37.7)\end{array}$ & Patients & $\begin{array}{l}\text { Quantitative, } \\
\text { prospective, } \\
\text { descriptive }\end{array}$ & $\begin{array}{l}\text { Evaluate the quality of life of } \\
\text { patients with urethral } \\
\text { stenosis followed by } \\
\text { internal urethrotomy under } \\
\text { direct vision. }\end{array}$ & $\begin{array}{l}\text { Difficulty in inserting the catheter; } \\
\text { urethral bleeding; pain in } \\
\text { performing the procedure. }\end{array}$ \\
\hline $34^{50}$ & $\begin{array}{c}78 \\
(36.4)\end{array}$ & Patients & $\begin{array}{l}\text { Quantitative, } \\
\text { transversal, } \\
\text { descriptive }\end{array}$ & $\begin{array}{l}\text { Identify the continuity rate of } \mathrm{CIC} \\
\text { and the barriers perceived for } \\
\text { carrying out and continuing } \\
\text { the procedure. }\end{array}$ & $\begin{array}{l}\text { Lack of accessibility in the } \\
\text { bathrooms; difficulty in obtaining } \\
\text { the necessary material to perform } \\
\text { the procedure. }\end{array}$ \\
\hline
\end{tabular}

\section{DISCUSSION}

Bladder catheterization is the technique of bladder emptying considered gold standard in the treatment of bladder-urinary dysfunctions. It is an effective and safe strategy that allows bladder emptying at regular intervals and prevents complications of urinary stasis. Besides the physical benefits, it promotes social inclusion, selfesteem and independence and can be performed by both patient and caregiver ${ }^{51,52}$.

Understanding that urinary stasis and high intravesical pressure were more important than the bacterial factor in the installation of urinary infections, in 1972 the technique of clean intermittent catheterization was introduced to replace the sterile technique, impractical in the patients' daily lives ${ }^{53}$. Thus, CIC aimed to reduce the costs of the sterile procedure and promote greater ease in performing the technique to its users, since it became easier and more objective, ensure its execution, ensure success in performing the procedure, increase adherence to treatment and thus reduce complications related to urinary retention ${ }^{14,54}$.

When compared to bladder delay catheterization, CIC shows advantage over ease and independence of use and lower infection and complications rates in the short and long term ${ }^{14,54}$.

Although CIC is considered an easy-to-perform technique, there are still doubts and uncertainties in its 
performance among health professionals and students. Many are the myths and rituals that permeate the process of hygiene, antisepsis, choice of materials that remain in the training of professionals ${ }^{55,56}$.

When the studies of this review were analyzed, the difficulty in catheter insertion was the most reported and may be related to several factors, whether intrinsic and/ or extrinsic, such as the patient's anatomy, manifestations of the basic pathology, infrastructure and materials used in the procedure. Among the studies analyzed, resistance in its introduction ${ }^{5,17,34,47}$, muscle spasms s $^{27,33,38,41}$ were cited as reasons for difficulty in inserting the catheter, difficulties of access to the urethra ${ }^{5,39,46}$, body positioning ${ }^{5,38,39}$, handling of prelubricated catheter ${ }^{27,28,45}$, dexterity ${ }^{35,46}$ and prostate enlargement ${ }^{20,36}$.

Pain was present in 12 studies $3,5,25,26,33,35,39-41,45,46,49$ and is usually related to urethral trauma and bleeding, which are also mentioned as difficulties $3,5,17,20,22,25,27-30,32-39,45-49$. The occurrence of these complications in the procedure causes discomfort ${ }^{3,28,31,33,35,39,40}$, worsens the experience of the individual in the use of CIC, impacts negatively on the quality of life and makes them factors that contribute to the discontinuation of treatment ${ }^{5}$.

Pain is a sensory and also an unpleasant emotional experience. Its manifestation is associated to effective or potential damage in tissues. It is a multidimensional phenomenon and comprises physical-sensory characteristics and emotional factors ${ }^{44,57}$.

Urethral trauma occurs by the insertion of a badly lubricated urinary catheter into the urethra. Due to the lack of lubrication, difficulties can occur in the introduction and, with the increase of the applied force, friction of the urinary catheter against the urethral mucosa occurs with its consequent lesion, causing pain and bleeding. By creating a gateway for microorganisms by rupturing the mucosa, urethral trauma is considered one of the main factors that leads to the development of urinary tract infection6. Urethral trauma may be related to the inputs used in the CIC and the lack of ability of patients and caregivers in the procedure $6^{, 58,59}$.

Besides urethral trauma, bleeding and resistance in the introduction of the urinary catheter are also pointed out as factors for decreasing confidence in the performance of CIC among patients, professionals and students ${ }^{17,60,61}$.

Lidocaine gel is the most widely used lubricant in Brazil to lubricate the urethra, and is effective in reducing pain and sensitivity, promoting some urethral dilation and facilitating the introduction of the urinary catheter, significantly reducing the risk of urethral trauma ${ }^{12,58}$. However several types of bladder catheters are available on the market. With more technology and in order to offer greater convenience and safety to users, the use of lubricated catheters is recommended. When compared to the traditional plastic catheter (polyvinyl chloride), the use of prelubricated or coated catheter is related to the reduction of urinary tract infection and urethral trauma, the ease and comfort during urinary catheterization ${ }^{9,10 .}$

However, despite demonstrating more safety and ease of use, some patients find it difficult to handle the prelubricated catheter. In three (8.8\%) studies analyzed, patients reported difficulty in handling the prelubricated catheter because it is slippery ${ }^{27,28,45}$. By reducing friction against the urethral mucosa and reducing pain during the procedure, prelubricated urinary catheters can lead to greater adherence to treatment and their use is related to the better quality of life of their users ${ }^{62}$.

Patients often find inadequate facilities in public bathrooms, from insipient physical structure to poor hygiene, lack of shelves for material preparation and poor lighting $3,23,33,34,38,39,42,43,50$. Because of the difficulties faced in public spaces with inappropriate locations for CIC, some patients choose to limit their activities to their homes and end up having restrictions on social life, where the lack of infrastructure induces isolation ${ }^{3}$.

Physical difficulties, both motor and visual, are often related to the basic pathology that led to the need for urinary catheterization for bladder emptying. Studies show that neurological disorders account for a large part of the basic diseases that lead to this need, followed by prostate problems and cancer ${ }^{38,63,64}$.

Motor difficulty and lack of manual dexterity contribute to the presence of difficulties and are usually the result of impaired motor function and sensitivity as a result of neurological diseases or impairments such as multiple sclerosis, Parkinson's disease, myelomeningocele, stroke and spinal cord injury $21,23,26,33,35,38,39,46$.

There are several clinical conditions that affect the central nervous system, which can result in changes in muscle tone and reduced activity of the musculoskeletal system, leading to disabling conditions such as spasticity, which can reduce the individual's functional capacity ${ }^{65}$. 
Muscle spasm is an involuntary motor activity, characterized by a motor disorder, repeated movements, increased muscle resistance, the presence of exaggerated tendon movements, hyperreflexia and hypertonia due to neuronal hyperexcitability ${ }^{66}$.

The studies mention that muscle spasms, resulting from basic diseases, make it difficult to perform the procedure because they affect mobility and dexterity until they prevent the introduction of the urinary catheter when it affects the urethral sphincter ${ }^{27,33,38,41}$. The visual difficulty mentioned is also related to neurological involvement and causes difficulties in performing the procedure, from the preparation of materials and intimate hygiene to the identification of the urethra and insertion of the urinary catheter ${ }^{21,35}$.

In this sense, in the evaluations performed during the initial period of bladder rehabilitation, it is necessary to evaluate the functional capacity of the patient to perform the urinary catheterization by himself, named autocatheterism, or to determine the need of a caregiver to perform the urinary elimination care in the use of $\mathrm{CIC}^{67}$.

Used in the evaluation of the skills for the practice of clean intermittent autocatheterism among patients with neurological disorders, a test called "pencil and assessment" was developed. The test proposes gestures and simulates maneuvers necessary to perform the procedure alone, analyzing the cognitive and physical resources indispensable for the development of the technique. The test is able to predict the ability of the practice of the procedure alone or indicate the need for help from a caregiver.

The absence of the caregiver was mentioned as a difficulty to carry out the CIC in some studies of this search, especially when they are in environments outside the home, such as school or work ${ }^{34,43}$.

Regarding female CIC users, studies point out the difficulty of visualizing the urethral meatus. This difficulty is due to the anatomical characteristics of the female genitalia, which makes visualization more difficult than in $\operatorname{men}^{5,33-35,37,39,44,46}$.

The female urethral meatus can be more distal or profound. In addition, older women generally have no clear knowledge of genital anatomy. To visualize more easily the urethral meatus, the use of the mirror is indicated ${ }^{5,46}$. However, with the improvement of skills, women are able to leave the mirror and identify the urethral meatus only through touch ${ }^{53}$.
A situation also restricted to women, menstrual flow was mentioned as a factor of difficulty in the execution of the technique. However, after performing the intimate hygiene, the procedure can be normally performed ${ }^{21,40}$.

The use of CIC generates significant changes in the life activities of patients who need to make use of it $^{62}$. Some patients consider that the time spent preparing the materials and performing the procedure are factors of difficulty in performing and adhering to the CIC, because they change the routine, become a burden and are limiting daily activities. For caregivers of CIC users, feelings of overload and limitation in their own life are also present ${ }^{28,34,40,43}$.

During the rehabilitation process, patients need to reorganize their psychosocial, family, routine and work context. These changes also involve financial factors and can generate costs related to the materials used in the procedure ${ }^{69}$.

In Brazil, there is still no specific policy to guarantee the materials used in the realization of the CIC.However, the Brazilian population is assisted by the Brazilian Unified Health System (SUS), which conceives health as a fundamental right of every human being and attributes to the State the duty of providing all the fundamental conditions for its full exercise, as well as guarantee reduction of risks of diseases and illnesses. In the principles of SUS, integral therapeutic assistance is also provided. Thus, by law, CIC users are entitled to receive all materials necessary for the execution of the procedure ${ }^{62,70}$.

However, the resources made available to users are not the most effective and safe indicated in the literature and sometimes they are not enough to meet their needs ${ }^{28,29,31}$. When facing scarcity of resources in the execution of the CIC, some users need to ration the inputs they have, being necessary to reduce the amount of lubricant applied and the reutilization of the same urinary catheter for several times $^{12,71}$.

A study conducted from a global perspective points out that this reality is related to the economic development of the nation. In developed countries, it was estimated that $83 \%$ of research participants using the CIC never needed to reuse the catheter. In developing countries, only $27 \%$ of the participants did not reuse it. Among participants from developing countries, the average number of urinary tract infections was twice as high as participants from developed countries ${ }^{71}$. 
In the reuse of the urinary catheter, there are reports in literature of several techniques used in hygiene for its reuse, such as putting the urinary catheter in boiling water, washing it in running water, storing it in a solution with vinegar, detergent or alcohol $70 \%$ or heating it in the microwave $^{64,72}$.

Even with the effective antimicrobial effect in some hygiene methods for urinary catheter reuse, studies show that reuse is directly related to the increased frequency of urinary tract infections ${ }^{71}$. Another study related the absence of adequate materials to the development of urethral trauma ${ }^{3}$.

Besides causing difficulties in performing the technique, the lack of access to adequate inputs is cited by CIC users as a factor that causes discontinuity in treatment, influences comfort during the procedure and can be determinant for the success or failure of the technique and patient compliance ${ }^{38,62}$.

No matter how easy it is to perform, patients and their caregivers still face several psychological, social and cultural issues, such as fear. Fear can be related to the concern of inserting a catheter into the body and causing pain, damage or injury to the urinary tract. It is a feeling present mainly in caregivers of children with preserved sensitivity. It usually comes from feelings of disability and may also be related to cultural beliefs and insufficient guidance. Therefore, health education during the rehabilitation process plays a fundamental role in overcoming the fears and difficulties encountered by CIC users and their caregivers ${ }^{25,31,44}$.

Patients with neurogenic bladder commonly have alterations in intestinal functions, due to its etiology, and may be affected by neurogenic bowel ${ }^{69,73}$. The neurogenic bowel can be defined by the interruption of central nervous system stimuli, which alters the process of storage and disposal of solid waste ${ }^{74,75}$. Among the most common complications are pain, constipation, fecal incontinence, fecal impaction, hemorrhoids, anal fissures, bleeding and rectal prolapse ${ }^{69,76}$.

A study conducted at a rehabilitation center indicated that approximately $50 \%$ of patients using CIC used antispasmodic and anticholinergic medications ${ }^{64}$. Used in the pharmacological treatment of overactive bladder, antispasmodics and anticholinergics act on the smooth musculature of the bladder and thus promote increased bladder capacity, decrease spasms of the detrusor muscle, delay the initial desire to urinate and decrease urgency, urinary frequency and incontinence ${ }^{77}$. In addition, the use of anticholinergic and antispasmodic drugs can inhibit gastric acid secretion and depress gastrointestinal motility, and can cause a constipation picture $\mathrm{e}^{78,79}$.

Patients with rectal distension may have their bladder capacity reduced by up to $26 \%$ and consequently have the first urination desire and the strongest desire with lower urine volume in the bladder when compared to the moment without any rectal distension ${ }^{79}$. Constipation and consequently fecal impaction are the most common multicausal involvement in the elderly and are associated with diet, dehydration, lack of physical activity, immobilization, medications and systemic diseases such as multiple sclerosis, cerebrovascular accident, dementia and spinal cord injury. In more severe and unusual cases, fecal impaction can completely obstruct the urinary tract, blocking the urethra, ureters or both ${ }^{80,81}$.

These added facts can generate urine loss due to reduced bladder storage capacity and, rarely, can cause difficulty or hindrance during catheter insertion due to fecal impaction and intestinal distension leading to urinary tract obstruction by mechanical compression, as reported in study 11 , which portrays the unusual case of a giant fecaloma ${ }^{30,79}$.

Complications of the neurogenic bowel can limit daily activities, causing psychosocial and economic impacts, and hinder the rehabilitation process ${ }^{69}$. Dissatisfied patients with impaired bowel elimination have a diminished perception of quality of life in relation to those who are satisfied, especially in relation to social function, work, pain and discomfort ${ }^{76}$.

Obesity also appeared as a difficulty, since it can lead to the inability to access the perineum due to the accumulation of abdominal fat and excessive skin around the perineum. The decrease in mobility related to some underlying diseases may be related to weight gain ${ }^{46}$.

\section{CONCLUSION}

The studies analyzed demonstrated the difficulties that CIC users and their caregivers face in their daily lives and are associated with intrinsic and extrinsic factors such as dexterity, manifestations of the underlying disease, infrastructure, access to materials and complications of CIC use. They are also related to institutional, socioeconomic 
and governmental factors. Such confrontations diminish user satisfaction, affect adherence to bladder rehabilitation programs, can cause damage to nontreatment and negatively impact the quality of life of patients and their caregivers. In this sense, efforts of the multidisciplinary team in health education are necessary for the proper implementation of the CIC.

Although this study is a review of scope and has fulfilled its role in mapping the problems encountered by patients using $\mathrm{CIC}$, it is possible to observe among the studies found that most of them are descriptive studies, conducted with different samples of patients and caregivers, mostly adults, but of different age groups, who were not stratified in this review. This can be considered a limiting factor of this work and should be explored in new research that also analyzes interventions.

\section{AUTHOR'S CONTRIBUTION}

Conceptualization: Orlandin L and Mazzo A; Methodology: Mazzo A and Nardi A; Investigation: Orlandin L; Mazzo A; Nardi A and Costa RRO; Writing - Original Draft: Orlandin L and Mazzo A; Writing - Review and Editing: Orlandin L; Mazzo A; Nardi A and Costa RRO; Supervision: Mazzo A and Nardi A.

\section{REFERENCES}

1. Di Benedetto P. Clean intermittent self-catheterization in neuro-urology. Eur J Phys Rehabil Med. 2011;47(4):651-9.

2. Vahr S, Cobussen-Boekhorst H, EikenboomJ, Geng V, Holroyd $\mathrm{S}$, Lester $\mathrm{M}$ et al. Catheterisation urethral intermittent in adults: Dilatation, urethral intermittent in adults. Evidencebased guidelines for best practice in urological health care. Netherlands: European Association of Urology Nurses; 2013.

3. Lopes MAL, Lima EDRP. Continuous use of intermittent bladder catheterization - can social support contribute? Rev Latino-Am Enfermagem. 2014;22(3):461-6. https://doi. org/10.1590/0104-1169.3268.2438

4. Bickhaus JA, Drobnis EZ, Critchlow WA, Occhino JA, Foster RT. The feasibility of clean intermittent self-catheterization teaching in an outpatient setting. Female Pelvic Med Reconstr Surg. 2015;21(4):220-4. https://doi.org/10.1097/ SPV.0000000000000155

5. Faleiros F, Pelosi G, Warschausky S, Tate D, Käppler C, Thomas E. Factors influencing the use of intermittent bladder catheterization by individuals with spina bifida in Brazil and Germany. Rehabil Nurs. 2018;43(1):46-51. https:// doi.org/10.1002/rnj.302

6. Newman DK, Willson MM. Review of intermittent catheterization and current best practices. Urol Nurs. 201;31(1):12-28. https://doi.org/10.7257/1053816X.2012.31.1.12

7. Mazzo A, Bardivia CB, Jorge BM, Souza Júnior VD, Fumincelli L, Mendes IAC. Cateterismo urinario permanente: práctica clínica. Enfermería Glob. 2015;14(2):50-77. https://doi. org/10.6018/eglobal.14.2.186251

8. Martins MS, Santos VLCG, Secoli SR, Mata SM, Nogueira DS, Souza DM. Estudo comparativo sobre dois tipos de cateteres para cateterismo intermitente limpo em crianças estomizadas. Rev Esc Enferm USP. 2009;43(4):865-71. https://doi.org/10.1590/S0080-62342009000400018

9. Sarica S, Akkoc $Y$, Karapolat $H$, Aktug $H$. Comparison of the use of conventional, hydrophilic and gel-lubricated catheters with regard to urethral micro trauma, urinary system infection, and patient satisfaction in patients with spinal cord injury: a randomized controlled study. Eur J Phys Rehabil Med. 2010;46(4):473-9.

10. Chartier-Kastler E, Denys P. Intermittent catheterization with hydrophilic catheters as a treatment of chronic neurogenic urinary retention. Neurourol Urodyn. 2011;30(1):21-31. https://doi.org/10.1002/nau.20929

11. Lamin E, Newman DK. Clean intermittent catheterization revisited. Int Urol Nephrol. 2016;48(6):931-9. https://doi. org/10.1007/s11255-016-1236-9

12. Mazzo A, Pecci GL, Fumincelli $L$, Neves RC, Santos RCR, Cassini MF, et al. Intermittent urethral catheterisation: the reality of the lubricants and catheters in the clinical practice of a Brazilian service. J Clin Nurs. 2016;25(21-22):3382-90. https://doi.org/10.1111/jocn.13466

13. Chan MF, Tan HY, Lian X, Ng LYG, Ang LLE, Lim LHL, et al. A randomized controlled study to compare the $2 \%$ lignocaine and aqueous lubricating gels for female urethral catheterization. Pain Pract. 2014;14(2):140-5. https://doi. org/10.1111/papr.12056

14. Ercole FF, Macieira TGR, Wenceslau LCC, Martins AR, Campos CC, Chianca TCM. Integrative review: evidences on the practice of intermittent/indwelling urinary catheterization. Rev Latino-Am Enfermagem. 2013;21(1):459-68. https://doi. org/10.1590/S0104-11692013000100023

15. Lima MB, Rebouças CBA, Castro RCMB, Cipriano MAB, Cardoso MVLML, Almeida PC. Construção e validação de vídeo educativo para orientação de pais de crianças 
em cateterismo intermitente limpo. Rev Esc Enferm USP. 2017;51:e03273. https://doi.org/10.1590/s1980$220 \times 2016005603273$

16. Roecker S, Budó MLD, Marcon SS. Trabalho educativo do enfermeiro na Estratégia Saúde da Família: dificuldades e perspectivas de mudanças. Rev Esc Enferm USP. 2012;46(3):641-9. https://doi.org/10.1590/S008062342012000300016

17. Orlandin L, Mazzo A, Meska MHG, Jorge BM, Cotta Filho CK, Fumincelli L. Low-fidelity simulation for patients and caregivers in the use of lubricants in clean intermittent catheterization. Int J Urol Nurs. 2018;12(1):9-15. https://doi. org/10.1111/ijun.12155

18. Peters MDJ, Godfrey C, Mclnerney P, Baldini SC, Khalil H, Parker D. Chapter 11: Scoping Reviews. In: Aromataris E, Munn Z, editors. Joanna Briggs Institute Reviewer's Manual. Adelaide: JBl; 2017.

19. Galvão CM, Sawada NO, Trevizan MA. Revisão sistemática: recurso que proporciona a incorporação das evidências na prática da enfermagem. Rev Latino-Am Enfermagem. 2004;12(3):549-56. https://doi.org/10.1590/S010411692004000300014

20. Bennett CJ, Diokno AC. Clean intermittent self-catheterization in the elderly. Urology. 1984;24(1):43-5. https://doi. org/10.1016/0090-4295(84)90386-8

21. Robinson RO, Cockram M, Strode M. Severe handicap in spina bifida: no bar to intermittent self catheterisation. Arch Dis Child. 1985;60(8):760-2. https://doi.org/10.1136/ adc.60.8.760

22. Perkash I, Friedland GW. Posterior ledge at the bladder neck: Crucial diagnostic role of ultrasonography. Urol Radiol. 1986;8(4):175-83. https://doi.org/10.1007/BF02924101

23. Neal DE, Lawson AL, Webb RJ, Robertson AS. Clean intermittent self-catheterization. Int Urogynecol J. 1993;4(1):50-5. https://doi.org/10.1007/BF00372814

24. Boemers TML, Soorani-Lunsing IJ, Jong TPVM, Pruijs HEH. Urological problems after surgical treatment of scoliosis in children with myelomeningocele. J Urol. 1996;155(3):1066-9. https://doi.org/10.1016/S0022-5347(01)66393-6

25. Boemers TML, Jong TPVM, van Gool JD, Bax KMA. Urologic problems in anorectal malformations. Part 2: Functional urologic sequelae. J Pediatr Surg. 1996;31(5):634-7. https:// doi.org/10.1016/S0022-3468(96)90663-6

26. Salle JLP, McLorie GA, Bägli DJ, Khoury AE. Modifications of and extended indications for the Pippi Salle procedure. World J Urol. 1998;16(4):279-84. https://doi.org/10.1007/ s003450050067

27. Wyndaele JJ, Ridder D, Everaert K, Heilporn A, CongardChassol B. Evaluation of the use of Urocath-Gel® catheters for intermittent self-catheterization by male patients using conventional catheters for a long time. Spinal Cord. 2000;38(2):97-9. https://doi.org/10.1038/sj.sc.3100958
28. Pereira PL, Urrutia MJM, Lobato L, Rivas S, Monereo EJ. Estudio comparativo del grado de satisfacción del paciente en cateterismo intermitente con el uso de las sondas lofric y las de cloruro de polivinilo. Actas Urol Esp. 2001;25(10):72530. https://doi.org/10.1016/S0210-4806(01)72708-8

29. Vapnek JM, Maynard FM, Kim J. A prospective randomized trial of the LoFric hydrophilic coated catheter versus conventional plastic catheter for clean intermittent catheterization. J Urol. 2003;169(3):994-8. https://doi. org/10.1097/01.ju.0000051160.72187.e9

30. Suzuki $K$, Sugaya $Y$, Tokue A. Giant stercoral stone and catheterization difficulty. Int J Urol. 2003;10(10):554-5. https://doi.org/10.1046/j.1442-2042.2003.00675.x

31. Alpert SA, Cheng EY, Zebold KF, Kaplan WE. Clean intermittent catheterization in genitally sensate children: patient experience and health related quality of life. J Urol. 2005;174(4):1616-9. https://doi.org/10.1097/01. ju.0000176620.02031.67

32. Lindehall B, Abrahamsson K, Jodal U, Olsson I, Sillén U. Complications of clean intermittent catheterization in young females with myelomeningocele: 10 to 19 years of followup. J Urol. 2007;178(3):1053-5. https://doi.org/10.1016/j. juro.2007.05.071

33. Shaw C, Logan K, Webber I, Broome L, Samuel S. Effect of clean intermittent self-catheterization on quality of life: a qualitative study. J Adv Nurs. 2008;61(6):641-50. https://doi. org/10.1111/j.1365-2648.2007.04556.x

34. Vaidyanathan S, Soni BM, Singh G, Oo T, Hughes PL. Barriers to implementing intermittent catheterisation in spinal cord injury patients in Northwest Regional Spinal Injuries Centre, Southport, U.K. Sci World J. 2011;5(11):77-85.

35. Rantell A. Intermittent self-catheterisation in women. Nurs Stand. 2012;26(42):61-8. https://doi.org/10.7748/ ns2012.06.26.42.61.c9164

36. Spernat $\mathrm{D}$, Woo HH. Mini-photoselective vaporization of the prostate for difficult intermittent self-catheterization. Koren J Urol. 2012;53(9):654-6. https://doi.org/10.4111/ kju.2012.53.9.654

37. Wu JA, Braschi EJ, Gulminello PL, Comiter CV. Labioplasty for hypertrophic labia minora contributing to recurrent urinary tract infections. Female Pelvic Med Reconstr Surg. 2013;19(2):121-3. https://doi.org/10.1097/ SPV.0b013e31827de473

38. Bolinger R, Engberg S. Barriers, complications, adherence, and self-reported quality of life for people using clean intermittent catheterization. J Wound Ostomy Continence Nurs. 2013;40(1):83-9. https://doi.org/10.1097/ WON.0b013e3182750117

39. Souza SM. Práticas de cuidado e desafios do autocateterismo intermitente limpo: as vozes dos escolares [dissertação]. [Rio de Janeiro]: Universidade do Estado do Rio de Janeiro; 2015.

40. Alencar VP. Cateterismo vesical intermitente limpo em crianças e adolescentes: análise da qualidade de vida do 
binômio cuidador-criança e dos fatores envolvidos [tese] [São Paulo]: Universidade de São Paulo; 2016.

41. Guinet-Lacoste A, Jousse M, Tan E, Caillebot M, Breton F, Amarenco G. Intermittent catheterization difficulty questionnaire (ICDQ): A new tool for the evaluation of patient difficulties with clean intermittent selfcatheterization. Neurourol Urodyn. 2016;35(1):85-9. https:// doi.org/10.1002/nau.22686

42. Cobussen-Boekhorst H, Hermeling E, Heesakkers J, van Gaal B. Patients' experience with intermittent catheterisation in everyday life. J Clin Nurs. 2016;25(9-10):1253-61. https://doi. org/10.1111/jocn.13146

43. Lim S-W, Lee H-E, Davis M, Park K. Perceived barriers and difficulties of intermittent catheterization: In Korean patients with spinal dysraphism and their parents. Neurourol Urodyn. 2016;35(3):395-9. https://doi.org/10.1002/nau.22716

44. Antonio S, Pacheco STA, Gomes MPF, Bossa PMA, Castro FM, Pereira MCR. Tradução dos sentimentos de familiares no cuidar da criança dependente do cateterismo intermitente limpo. Rev Enferm UERJ. 2016;24(4):e19990. https://doi. org/10.12957/reuerj.2016.19990

45. DeFoor W, Reddy P, Reed M, VanderBrink B, Jackson E, Zhang $B$, et al. Results of a prospective randomized control trial comparing hydrophilic to uncoated catheters in children with neurogenic bladder. J Pediatr Urol. 2017;13(4):373.E15. https://doi.org/10.1016/j.jpurol.2017.06.003

46. Hentzen C, Haddad R, Ismael SS, Peyronnet B, Gamé X, Denys $P$, et al. Intermittent self-catheterization in older adults: predictors of success for technique learning. Int Neurourol J. 2018;22(1):65-71. https://doi.org/10.5213/ inj.1835008.504

47. Montovasseli D, Chesnel C, Charlanes A, Menoux $D$, Charoenwong F, Le Breton F, et al. Adherence to anticholinergic therapy and clean intermittent selfcatheterization in patients with multiple sclerosis. Int Neurourol J. 2018;22(2):133-41. https://doi.org/10.5213/ inj.1836054.027

48. Sharif MM, Kazmi SAM, Mukhtar M, Khan AZ. Role of intermittent self catheterization after cauda equina syndrome surgery. JRMC. 2018;22(1):54-7.

49. Jhanwar A, Sokhal AK, Singh K, Sankhwar S, Saini DK. Assessment of quality of life in patients of urethral stricture on clean intermittent catheterization following direct vision internal urethrotomy. Urol Ann. 2018;10(4):395-9. https:// doi.org/10.4103/UA.UA_34_17

50. Baniya M, Groves CC, Bhattarai M. Intermittent catheterisation practice of people with spinal cord injury in five districts of Nepal. Australian and New Zealand Continence Journal. 2019;25(1):10-5.

51. Woodward S, Rew M. Patients' quality of life and clean intermittent self-catheterization. BrJ Nurs. 2003;12(18):106674. https://doi.org/10.12968/bjon.2003.12.18.11782
52. Assis GM, Faro ACM. Autocateterismo vesical intermitente na lesão medular. Rev Esc Enferm USP. 2011;45(1):289-93. https://doi.org/10.1590/S0080-62342011000100041

53. Lapides J, Diokno AC, Silber SJ, Lowe BS. Clean, intermittent self-catheterization in the treatment of urinary tract disease. J Urol. 1972;107(3):458-61. https://doi.org/10.1016/500225347(17)61055-3

54. Zambon JP, Cintra CC, Bezerra CA, Bicudo MC, Wroclawsk ER. What is the best choice for chronic urinary retention: indwelling catheter or clean intermittent catheterization? Einstein. 2009;7(4):520-4.

55. Mazzo A, Godoy S, Alves LM, Mendes IAC, Trevizan MA, Rangel EML. Cateterismo urinário: facilidades e dificuldades relacionadas à sua padronização. Texto Contexto Enferm. 2011;20(2):333-9. https://doi.org/10.1590/S010407072011000200016

56. Dourado DX, Valença MP. Avaliação do conhecimento dos enfermeiros sobre o cateterismo intermitente limpo em um hospital escola da cidade do Recife. ESTIMA, Braz J Enterostomal Ther. 2013;11(1):2.

57. Kopf A, Patel NB. Guide to pain management in low-resource settings. Washington: IASP; 2010.

58. Bardsley A. Use of lubricant gels in urinary catheterisation. Nurs Stand. 2005;20(8):41-6. https://doi.org/10.7748/ ns2005.11.20.8.41.c3992

59. Kashefi C, Messer K, Barden R, Sexton C, Parsons JK. Incidence and prevention of iatrogenic urethral injuries. J Urol. 2008;179(6):2254-8. https://doi.org/10.1016/j. juro.2008.01.108

60. Mazzo A, Martins JCA, Jorge BM, Baptista RCN, Almeida RGS, Henriques FMD, et al. Validation of the selfconfidence scale of nursing care in urinary retention. Rev Latino-Am Enfermagem. 2015;23(5):814-20. https://doi. org/10.1590/0104-1169.0256.2619

61. Silva DR, Mazzo A, Jorge BM, Souza Júnior VD, Fumincelli L, Almeida RGS. Intermittent urinary catheterization: the impact of training on a low-fidelity simulator on the self-confidence of patients and caregivers. Rehabil Nurs. 2017;42(2):97-103. https://doi.org/10.1002/rnj.226

62. Fumincelli L, Mazzo A, Martins JCA, Henriques FMD, Orlandin L. Quality of life of patients using intermittent urinary catheterization. Rev Latino-Am Enfermagem. 2017;25:e2906. https://doi.org/10.1590/1518-8345.1816.2906

63. Silva MB, Oliveira LFT, Ferreira ML, Santos LCR. Cateterismo Vesical Intermitente: Análise Epidemiológica. ESTIMA, Braz J Enterostomal Ther. 2005;3(1).

64. Mazzo A, Souza Júnior VD, Jorge BM, Fumincelli L, Trevizan MA, Ventura CAA, et al. Qualidade e segurança do cuidado de enfermagem ao paciente usuário de cateterismo urinário intermitente. Esc Anna Nery. 2017;21(2):e20170045.

65. Pavan K, Marangoni BEM, Shimizu WAL, Mattos SE, Ferrari PP, Martins SRG, et al. Validation of the Santa Casa evaluation 
of spasticity scale. Arq Neuro-Psiquiatr. 2010;68(1):56-61. https://doi.org/10.1590/50004-282X2010000100013

66. Bolaños-Jiménez R, Arizmendi-Vargas J, Calderón-Álvarez TJL, Carrillo-Ruiz JD, Rivera-Silva G, Jiménez-Ponce F. Espasticidad, conceptos fisiológicos y fisiopatológicos aplicados a la clínica. Rev Mex Neuroci. 2011;12(3):141-8.

67. Seth JH, Haslam C, Panicker JN. Ensuring patient adherence to clean intermittent self-catheterization. Patient Prefer Adherence. 2014;8:191-8. https://doi.org/10.2147/PPA.S49060

68. Amarenco G, Guinet A, Jousse M, Verollet D, Ismael SS. Pencil and paper test: A new tool to predict the ability of neurological patients to practice clean intermittent selfcatheterization. J Urol. 2011;185(2):578-82. https://doi. org/10.1016/j.juro.2010.09.106

69. Santos RCR, Fumincelli L, Nassif A, Souza Júnior VD, Jorge BM, Mazzo A. Paciente com bexiga neurogênica: cateterismo urinário intermitente e cuidados intestinais. Rev Enferm UFPE online. 2015;9(Supl. 7):8953-60.

70. Brasil. Lei ñ. 8.080, de 19 de setembro de 1990. Dispõe sobre as condições para a promoção, proteção e recuperação da saúde, a organização e o funcionamento dos serviços correspondentes e dá outras providências. Diário Oficial da União 19 set 1990. [cited on 7 Sep 2019]. Available at: http:// www.planalto.gov.br/ccivil_03/leis//8080.htm

71. Krassioukov A, Cragg JJ, West C, Voss C, Krassioukov-Enns D. The good, the bad and the ugly of catheterization practices among elite athletes with spinal cord injury: a global perspective. Spinal Cord. 2015;53(1):78-82. https://doi. org/10.1038/sc.2014.208

72. Bogaert GA, Goeman L, Ridder D, Wevers M, Ivens J, Schuermans A. The physical and antimicrobial effects of microwave heating and alcohol immersion on catheters that are reused for clean intermittent catheterisation. Eur Urol. 2004;46(5):641-6. https://doi.org/10.1016/j. eururo.2004.06.016
73. Lie HR, Lagergren J, Rasmussen F, Lagerkvist B, Hagelsteen J, Börjeson M-C, et al. Bowel and bladder control of children with myelomeningocele: a Nordic study. Dev Med Child Neurol. 1991;33(12):1053-61. https://doi. org/10.1111/j.1469-8749.1991.tb14827.x

74. Bruni DS, Strazzieri KC, Gumieiro MN, Giovanazzi R, Sá VG, Faro ACM. Aspectos fisiopatológicos e assistenciais de enfermagem na reabilitação da pessoa com lesão medular. Rev Esc Enferm USP. 2004;38(1):71-9. https://doi. org/10.1590/S0080-62342004000100009

75. Furlan MLS, Caliri MHL, Defino HL. Intestino neurogênico: Guia prático para pessoas com lesão medular - Parte I. Coluna/Columna. 2005;4(3):113-68.

76. Pardee C, Bricker D, Rundquist J, MacRae C, Tebben C. Characteristics of neurogenic bowel in spinal cord injury and perceived quality of life. Rehabil Nurs. 2012;37(3):12835. https://doi.org/10.1002/RNJ.00024

77. Ávila LC editor. AME - Dicionário de administração de medicamentos na enfermagem. São Paulo: Epub; 2013.

78. Potter PA, Perry AG. Fundamentos de Enfermagem. Rio de Janeiro: Elsevier; 2009.

79. Panayi DC, Khullar V, Digesu GA, Spiteri M, Hendricken C, Fernando R. Rectal distension: The effect on bladder function. Neurourol Urodyn. 2011;30(3):344-7. https://doi. org/10.1002/nau.20944

80. Knobel B, Rosman P, Gewurtz G. Bilateral hydronephrosis due to fecaloma in an elderly woman. J Clin Gastroenterol. 2000;30(3):311-3. https://doi.org/10.1097/00004836200004000-00022

81. Yuan R, Zhao GG, Papez S, Cleary JP, Heliotis A. Urethral obstruction and bilateral ureteral hydronephroses secondary to fecal impaction. J Clin Gastroenterol. 2000;30(3):314-6. https://doi.org/10.1097/00004836-200004000-00023 